\title{
MAKSIM PILIHAN DALAM KESANTUNAN BERBAHASA MAHASISWA DI KOTA BANJARMASIN
}

\section{Dana Aswadi dan Ahmad HB}

Pendidikan Bahasa dan Sastra Indonesia STKIP PGRI Banjarmasin

Jalan Sultan Adam, Komplek H. Iyus, No. 18 RT.23 Banjarmasin,

Kalimantan Selatan. Kode pos 70121

email: dadan899@yahoo.co.id

\begin{abstract}
ABSTRAK
Bahasa menjadi unsur utama dalam komunikasi sehari-hari. Dengan bahasa, manusia saling berhubungan antar sesama, sehingga bahasa menjadi alat utama dalam berkomunikasi. Manusia sudah sejak lama saling berhubungan dengan menggunakan bahasa, bahkan sudah berabad-abad yang lalu.

Adapun metode yang digunakan oleh peneliti dalam meneliti degredasi kesantunan berbahasa ini adalah dengan metode deskriptif. Pendekatan merupakan salah satu cara merancang penelitian sesuai dengan jenis penelitian itu sendiri. Pendekatan yang digunakan dalam penelitian ini adalah pendekatan kualitatif. Teknik pengumpulan data merupakan usaha-usaha untuk mengumpulkan data dan informasi dalam suatu penelitian. Adapun teknik pengumpulan data pada penelitian ini adalah teknik observasi.

Segi skala ketegasan ditemukan ada dua belas konteks yang terjadi pelanggaran, yakni pada (1) percakapan pertama sebanyak dua konteks, yaitu konteks keempat dan kesebelas, (2) percakapan kedua sebanyak tiga konteks, yaitu konteks lima, enam, dan lima belas, (3) percakapan ketiga sebanyak tiga konteks, yaitu konteks kesembilan, kesebelas, keenam belas, dan (4) percakapan keempat sebanyak dua konteks, yaitu konteks kedua, keempat, keenam, kedelapan.
\end{abstract}

Kata Kunci: kesantunan berbahasa, maksim pilihan

\section{PENDAHULUAN}

Bahasa menjadi unsur utama dalam komunikasi sehari-hari. Dengan bahasa, manusia saling berhubungan antar sesama, sehingga bahasa menjadi alat utama dalam berkomunikasi. Manusia sudah sejak lama saling berhubungan dengan menggunakan bahasa, bahkan sudah berabad-abad yang lalu. Penggunaan bahasa memiliki bentuk dalam penyampaian berdasarkan medianya, terutama bahasa dengan bentuk lisan.

Sadar maupun tidak sadar manusia selalu dihadapkan pada komunikasi. Dengan komunikasi tersebut, manusia bisa mengetahui berbagai informasi. Bukan hanya informasi yang disampaikan, 
bahasa juga menyampaikan berbagai emosional seseorang. Penyampaian emosional ini akan menmggerakkan berbagai aktifitas dalam kehidupan manusia itu sendiri.

Ada yang mengatakan bahwa dengan bahasa maka seseorang akan menguasai dunia. Hal tersebut menunjukkan bahwa bahasa menjadi salah satu hal yang sangat diperhatikan. Bahasa mampu membuat seseorang dihormati bahkan bahasa juga mampu membuat seseorang tidak dihormati. Bahasa mampu menunjukkan berbagai karakter manusia sehingga bahasa mampu memberikan efek tertentu kepada pendengarnya.

Semua hal di atas berkenaan dengan bagaimana pemakaian bahasa pada pemakai bahasanya. Bahasa mampu memberikan dampak tertentu tergantung penggunaannya. Penggunaan bahasa ini sangat penting diperhatikan. Apalagi bahasa ini selalu dihubungkan dengan kesantunan berbahasa. Seseorang akan dipandang apakah memiliki keseopansantunan terhadap bahasa atau tidak. Antara orang yang menyampaikan pesan dan orang yang menerima pesan akan saling berhubungan dengan bahasa ini, sehingga efek penggunaan akan tampak sesuai dengan penggunaannya. Oleh karena itu, kesantunan berbahasa sangat diperlukan. Bahkan, Wijana (1996:55) mengatakan bahwa prinsip kesopanan berhubungan dengan dua peserta percakapan, yakni diri sendiri (self) dan orang lain (other). Hal ini sangat jelas bahwa orang pertama dan orang kedua dalam kesantunan berbahasa sangat diperlukan.

Salah satu yang mengaflikasikan kesantunan berbahasa ini adalah para mahasiswa. Mahasiswa sebagai kaum intelektual sayogiyanya memiliki daya berpikir yang logis serta sistemis. Secara pemilihan katanya masuk akal, terdapat keberterimaan sehingga bagi orang yang mendengar akan mudah memahami apa yang disampaikannya. Bahkan, bahasanyapun memiliki etika sesuai dengan pendidikan yang dijalaninya. Bahasa yang sistemis digunakan oleh mahasiswa bahwa bahasa yang disampaikan berurutan, tidak acak, serta selalu memunculkan keefektifan dalam berbahasanya. Bukan hanya dua hal tersebut, mahasiswa juga harus memiliki bahasa yang santun. Hal tersebut dikarenakan dalam kampus mereka selalu diajarkan bagaimana bersikap serta berbahasa yang santun dengan berbagai aturan yang dibuat. Akan tetapi, tidak menutupkemungkinan bahwa mahasiswa juga tidak menggunakan bahasa yang tidak santunm ketika di kampus. Hal tersebut dikarenakan berbagai faktor yang mempengaruhinya, baik secara internal dirinya maupun pergaulan eksternal di luar kampus.

Mahasiwa sendiri akan menggunakan bahasa Indonesia (waktu yang formal) ketika berada di perkuliahan, serta menggunakan bahasa daerah (waktu yang tidak formal) ketika berada di luar dari perkuliahan/ pergaulan mereka sehari-hari. Ketika diperkuliahan, bahasa mahasiswa bisa dikontrol oleh dosen pengajar. Akan tetapi, ketika sudah berada di luar perkuliahan, mahasiswa pun secara bebas menggunakan bahasa. Hanya, secara aflikasinya saja lagi, apakah ingin menggunakan bahasa seperti yang diajarkan serta disampaikan sewaktu perkuliahan atau mengikuti pengaruh dari bahasa 
luar perkuliahan. Hal tersebut nantinya akan menentukan degradasi bahasa yang ada pada mahasiswa.

Bahasa mahasiswa sekarang ini sudah mulai terjadi degradasi kesantunan berbahasa. Degredasi tersebut disebabkan berbagai faktor. Dengan penelitian ini, kita akan mengetahui faktor apa saja yang menyebabkan degredasi kesantunan berbahasa pada mahasiswa tersebut.

Salah satu bahasa mahasiswa perguruan tinggi yang menarik untuk diamati adalah bahasa mahasiswa di Kota Banjarmasin. Dipilihnya mahasiswa di Kota Banjarmasin dikarenakan beberapa hal, antara lain; pertama, Mahasiswa merupakan peserta didik yang belajar di perguruan tinggi yang mencetak para intelektual. Bukan hanya dari segi materi yang diberikan kepada mahasiswa bahkan mereka juga diberikan bekal berkenaan dengan bagaimana penggunaan bahasa secara santun. Diharapkan, mahasiswa ini nantinya mampu memberikan materi dengan bahasa yang santun. Kedua, sebagai perguruan tinggi yang mencetak para intelektual yang bercendekia, setiap perguruan tinggi memiliki salah satu konsentrasi terhadap pembinaan bahasa mahasiswanya, sehingga mahasiswanya pun harus mampu dan mengaflikasikan penggunaan bahasa secara santun. Kemudian, ketiga, para mahasiswa yang kuliah di perguruan tinggi yang bereada di Banjarmasin pastinya sudah mengetahui serta menyadari bahwa mereka nantinya akan menjadi teladan sehingga di lingkungan kampus bahkan luar kampus pun mereka harus tetap menggunakan bahasa yang santun ketika berkomunikasi dengan orang lain.

Apa yang disampaikan di atas mengharuskan bahwa seorang mahasiswa harus memiliki bahasa yang santun. Akan tetapi, pada kenyataannya, faktor penyebab degradasi bahasa yang santun pun terjadi dengan berbagai faktornya. Oleh sebab itu, penelitian tentang degradasi ini sangat penting sekali untuk dilaksanakan.

\section{METODE}

Adapun metode yang digunakan oleh peneliti dalam meneliti degredasi kesantunan berbahasa ini adalah dengan metode deskriptif.

Metode deskriptif seperti yang dijelaskan oleh Nawawi yang disampaikan oleh Siswantoro (2016:56) bahwa metode deskriptif dapat diartikan sebagai prosedur pemecahan masalah yang diselidiki dengan menggambarkan atau melukiskan keadaan subjek atau objek penelitian...berdasarkan fakta-fakta yang tampak atau sebagaimana adanya.

Pendekatan merupakan salah satu cara merancang penelitian sesuai dengan jenis penelitian itu sendiri. Pendekatan yang digunakan dalam penelitian ini adalah pendekatan kualitatif. Menurut Bogdan dan Tylor dalam Moleong (2001) pendekatan kualitatif adalah prosedur penelitian yang menghasilkan data deskriptif berupa kata-kata tertulis maupun lisan dari orang-orang dan perilaku yang dapat diamati. Penelitian ini juga menggunakan pendekatan pragmatik. Pendekatan pragmatik 
merupakan pendekatan yang digunakan dengan mengaflikasikan ilmu pragmatik dalam penelitian tersebut.

Teknik pengumpulan data merupakan usaha-usaha untuk mengumpulkan data dan informasi dalam suatu penelitian. Adapun teknik pengumpulan data pada penelitian ini adalah teknik observasi

\section{HASIL DAN PEMBAHASAN}

Skala ketidaktegasan (skala pilihan) yaitu antara penutur dan mitra tutur melakukan pilihan tuturan agar terjalin tuturan yang harmonis dan tidak kaku. Pilihan bahasa dalam bertutur sangat diperlukan, baik oleh si pesapa maupun si penyapa. Pemilihan bahasa ini menjadikan tuturan menjadi lebih efektif dan saling korelasi satu dengan yang lainnya. Apabila tuturan ini tidak saling memiliki korelasi disebabkan pemilihan bahasa dalam bertutur kurang cermat maka akan memunculkan kekakuan dalam percakapannya. Lihat kutipan P1.K4 di bawah ini.

eh, esok liburan kalu jar? (Eh, besok liburankan?)

konteks P1.K4 di atas berupa pertanyaan berkenaan dengan hari yang akan datang. Pertanyaan dengan keraguan muncul. Hal ini juga dikarena pengetahuan si penyapa kepada di pesapa sehingga memunculkan pertanyaan. Konteks tersebut akan diketahui sebagai konteks yang tidak sesuai dengan kekorelasian dalam percakapan sehingga dianggap melanggar skala ketidaktegasan melalui wacana percakapan yang memunculkan pertanyaan tersebut muncul. Lihat wacana percakapan berikut.

P1 : nang kiapa tadi tugasnya? (Bagaimana tugas tadi?)

P2 : pahamai kalu ikam? (Kamu paham sajakan?)

P1 : kada pahamkam aku. (aku tidak paham)

P2 : eh, esok liburan kalu jar (iya, besok liburan kan?)

P1 : liburan, jar siapa ikam? (Liburan, kamu kata siapa?)

$\mathrm{P} 2$ : eeh, liburan jar. (iya, liburan katanya)

P2 : kita esok jalanankah (Besok kita jalan?)

$\mathrm{P} 1$ : kamanaan? Aku ini kulir pang. Handak guring haja Aku (Kemana? Aku ini malas. Mau tidur saja)

P2 : Iya kah. Mbah, kada rami am bila kadada ikam (yang benar. Bah, tidak ramai apabila tidak ada kamu)

P2 : iih kada rami. Biasanya ikam nang maramiakan yan ai (Iya, tidak ramai. Kamu biasanya yang buat ramai yan)

P1 : tugas tadi kiapa (Bagaimana tugas tadi)

P2 : kaina kubatakun lawan bagiannya, lawan enab, biasanya inya to paham (aku tanyakan dengan yang lain nanti, enab biasanya paham)

P1 : ayoha, aku umpat jua kaina lah batakun lawan ikam 


\section{bila sudah kam takuni (iya, aku nanti ikut juga tanya dengan kamu apabila kamu sudah tanya) \\ P2 : oke,siap haja (Oke, siap saja)}

Wacana percakapan di atas memberikan pengetahuan bahwa terdapat beberapa konteks yang tidak tepat diucapkan. Awalnya, penyapa dan pesapa membahas tentang tugas. Hal ini nampak pada sebuah teks inisiasi berupa pertanyaan nang kiapa tadi tugasnya? (Bagaimana tugas tadi?). Artinya, pembicara pertama disini memulai sebuah percakapan dengan pembahasa berkenaan dengan ketidaktahuan atau ketidakmnegertiannya tehadap tugas yang diberikan. Hal ini menunjukkan bahwa konteks percakapannya berkenaan dengan tugas. Kemudian, pesapa pun memberikan respon dengan menjawab berupa teks pertanyaan juga pahamai kalu ikam? (Kamu paham sajakan?). Munculnya pertanyaan maka harus diberikan jawaban, tetapi pembicara kedua disini ingin menggali dulu berkenaan dengan pemahaman pembicara pertama. Pembicara kedua ingin mengetahui tingkat pemahaman dari pembicara pertama. Pembicara pertama mendapatkan pertanyaan seperti itu maka memberikan balasan/ menjawab pertanyaannya kada pahamkam aku. (aku tidak paham). Hal ini pembicara kedua sudah mendapatkan informasi berkenaan dengan pemahaman pembicara kedua berkenaan dengan tugas. Setelah ini, pembicara kedua seharusnya sudah memberikan jawaban berupa penjelasan berkenaan dengan tugas yang sudah diberikan di kampus. Akan tetapi, si pembicara kedua memberikan pertanyaan lagi dengan pertanyaan yang berbeda, yaitu eh, esok liburan kalu jar? (Eh, besok liburankan?). Artinya, pertanyaannya tidak berhubungan dengan pembahasan sebelumnya. Oleh sebab itu, pertanyaan yang dilakukan ini dianggap tidak memiliki pemilihan bahasa yang tepat sesuai dengan pembahasan yang ada.

Pelanggaran dalam skala ini juga terdapat dalam wacana percakapan yang sama tetapi berbeda teksnya. Hal ini dikarenakan perpindahan konteks percakapan yang awalnya berbicara tentang tugas, kemudian liburan, dan kembali lagi kepermasalahan tugas. Lihat kutipan P1.K11 berikut.

tugas tadi kiapa (Bagaimana tugas tadi). (P1.K11)

Kutipan P1.K11 ini menunjukkan ketidaksantuanan terjadi karena pemilihan percakapan tidak sesuai dengan konteks sebelumnya. Konteks sebelumnya membeicarakan tentang liburan. Akan tetapi, dilanjutkan lagi dengan pertanyaan dengan membahas tugas. Hal ini tidak dibenarkan walaupun pembahasan awalnya masalah tugas tetapi pembahasannya sudah beralih dikarenakan ketidaksesuaian dalam pemilihan bahasa sehingga mengarah kepada liburan. Oleh karena itu, konteks tersebut di atas tidak memiliki pemilihan bahasa yang tepat sehingga melanggar skala ketidaktegasan (pilihan) yang mengakibatkan ketidaksantunan dalam berbahasa karena 
ketidakteraturan bahasanya. Ketidakteraturan bahasa ini akhirnya membuat kesalahan dalam memilih bahasa yang tepat untuk diucapkan pada waktu itu.

Percakapan yang bertentangan dengan skala ini juga terdapat dalam percakapan berikut.

P1 : el, bapa masuklah hari ini jar? Ujar habar sidin haur $l u(\mathrm{El}$, Apakah bapa hari ini masuk? Menurut kabar beliau sibuk)

P2 : kada tahu jua, katua tuh manakuni (Tidak tau, ketua yang ditanya)

P1 : katua, cuba pang ikam hubungi bapa. Masukkah hari ini atau kada kah.

Napang, ujar habar sidin haur lu. Sidin pina kada talihat jua mulai tadi. (Ketua, Kamu coba menghubungi bapa. Masuk atau tidak hari ini. Menurut kabar ia sibuk. Ia tidak terlihat juga dari tadi)

P1 : ikam ja nah manakuni. Aku kadada pulsa (kamu saja yang menanyakan. Aku tidak ada pulsa)

$\mathrm{P} 2$ : di WA haja manakuni (Lewat WA saja menanyakan)

P1 : eeh, ku WA nah sidinnya (Baik, aku WA beliau)

P2 : kadada marid lagi nah sidinnya. Haur lo sidin. (Tidak ada me-read lagi beliau. Kemungkinan beliau sibuk)

P1 : bisa ai to (Bisa juga)

P3 : eh, bagiannya balum datangan ah lagi. Kita PkN lo jam ini. (Eh, yang lain belum datang lagi? Kita PkN kan jam sekarang)

P1 : balum lagi, hanyar jam 9. Kita masuk jam 9.30 lo (Belum lagi, baru jam 9. Kita masuk jam 09.30 kan?)

P3 : mbah, jam ku nih tadahulu. Ku kada ingat kudahuluakan 15 menit (Aduh, jam aku ini lebih cepat. Aku lupa dipercepat 15 menit)

P2 : ada-ada haja ikam nih. Nyata ai dimajuakan kaitu. Kita ke perpus ah dulu (ada-ada saja kamu ini. Pasti saja dipercepat seperti itu. Kita ke perpus dulu!)

P1 : ayo, kita nah (ayo, kita)

P3 : aku kada umpat lah, disini haja (aku tidak ikut, disini saja)

$\mathrm{P} 2$ : eeh ayo ha (iya, baik)

P1 : kami ke perpus dahulu lah. Kaina bila ibu PkN datang, WA ja kami (kami ke perpus dulu. Nanti, apabila ibu PkN datang, WA saja kami)

$\mathrm{P} 2$ : sip, kena ku WA (sip, nanti aku WA)

Wacana percakapan di atas membahas berkenaan dengan seorang pengajar yang kemungkinan tidak bisa hadir/ tidak hadir untuk memberikan mata kuliah. Kemudian, pembahasan menjadi kurang sinkron ketika datang orang ketiga dan langsung memberikan sebuah pertanyaan. Pertanyaan ini akhirnya memberikan suatu alternatif baru dalam pembahasan sehingga antara pembahasan sebelumnya dengan pembahasan yang baru muncul tidak memiliki keterkaitan. Hal ini dikarenakan ketidaktahuan orang ketiga atau pembicara ketiga ini terhadap bahan yang dibicarakan 
oleh pihak pertama dan pihak kedua. Hal ini muncul dengan adanya kemunculan dari inisiasi yang dilakukan oleh pihak ketiga.

Lihat kutipan P3.K9 berikut.

eh, bagiannya balum datangan ah lagi. Kita PkN lo jam ini (eh, Apakah yang lain belum datang lagi)

Sebagaimana yang telah diuraikan di atas, pada konteks sebelumnya membicarakan tentang seorang tenaga pengajar yang diprediksikan tidak bisa masuk. Oleh karena itu, konteks itu membicarakannya. Konteks selanjutnya memunculkan sebuah konteks yang pembahasannya mulai menyimpang dari konteks sebelumnya. Kelanjutan dari konteks selanjutnya seharusnya masih membahas dosen yang tidak bisa masuk. Akan tetapi, konteks selanjutnya dikarenakan penuturnya yang tidak mengetahui pembahasan apa yang dibahas maka dituturkan sebuah konteks pertanyaan yang berbeda. Konteks eh, bagiannya balum datangan ah lagi. Kita PkN lo jam ini (eh, Apakah yang lain belum datang lagi) tidak seharusnya muncul. Konteks ini mempertanyakan teman sekelas yang masih belum datang sedangkan konteks di atas tidak ada menunjukkan atau membahas tentang teman sekelasnya. Bahkan, konteks ini juga memuat pertanyaan tentang mata kuliah PkN yang terjadwal pada hari tersebut. Hal ini juga bertentangan dengan konteks sebelumnya. Oleh karena itu, ketika seseorang ingin berbicara, maka dengarkan serta pelajari apa pokok permasalahan yang dibicarakan. Hal ini bisa menyebabkan kurangnya kesantunan berbahasa serta memotong pembahasan yang sudah berjalan.

Bukan hanya dari segi bahasanya, ternyata kesalahan pemilihan bahasa juga terdapat dalam ranah katanya. Ranah kata ini membuat kecanggungan dalam bahasa secara menyeluruh. Hal ini juga diakibatkan dari tingkat pengetahuan si penutur berkenaan dengan kata mana yang cocok digunakan yang tidak menimbulkan nilai negatif bagi si pendengar. Jadi, antara penyapa dan pesapa harus menjaga serta memilih kata yang sesuai dan cocok digunakan. Lihat kutipan P2.K5 berikut.

ikam masan jua tuh. Sungung banar nih (kamu memesan juga. Sangat bodoh ini). (P2.K5)

Konteks di atas menunjukkan ketidaksantunan secara eksplesit. Hal ini jelas terlihat dari pilihan katanya yang bertentangan dengan skala pilihan. Seharusnya, dia memilih kata yang santun, yaitu kata-kata yang tidak menimbulkan perasaan orang tersakiti. Pemilihan kata yang baik. Pemilihan kata yang baik akan menjadikan penyapa maupun pesapa terkonsulidasi dengan perkataan yang santun. Perkataan santun secara intens akan memberikan kedua percakapan lebih baik lagi dan tidak memunculkan kecanggungan. Konteks percakapan ini memunculkan kata 
sungung (bodoh). Kata sungung ini memberikan efek negatif bagi pendengar bahkan dia juga memiliki makna yang negatif sehingga pemilihan kata yang memilih kata sungung ini dianggap suatu pemilihan kata yang salah dalam percakapan yang akhirnya memunculkan ketidaksantunan bahasa.

Kemudian, kata sungung ini pun digunakan kembali oleh lawan tuturnya sebagai ejekan kepada lawan tutur. Dari konteks pertama dan kedua yang sama-sama menggunakan kata sungung ini maka keduanya menunjukkan adanya korelasi antara penyapa dengan pesapa yang memiliki pemilihan kata-kata yang sama negatif sehingga keduanya memang tidak memiliki kecanggungan. Akan tetapi, kata tersebut tetaplah merupakan kata yang negatif yang tidak patut disampaikan karena memiliki makna negatif dan dianggap kurang santun apabila digunakan. Lihat kutipan P2.K6 berikut.

nyawa tuh sungung. Apa tuh nang kam bawa li (Kamu itu yang bodoh. Apa yang kamu bawa itu li). (P2.K6)

kutipan P2.K6 di atas menunjukkan balasan atau jawaban dari konteks sebelumnya. Penutur ini pun menggunakan kata sungung sehingga dianggap ketidaksantunan di dalamnya. Ketika kata yang tidak santun ini diucapkan maka ia pun menutupnya dengan konteks Apa tuh nang kam bawa li (Apa yang kamu bawa itu li). Percakapan berupa pertanyaan ini diucapkan agar kecanggungan serta ketidaknyamanan karena kata sungung itu diucapkan menjadi teralihkan dengannya. Hal ini dikarenakan apabila kata yang mengandung ketidaksantunan berupa ejekan tersebut tetap dilanjutkan maka kemungkinan akan terjadi ketidaksinambungan bahasa yang membuat pertengkaran ke depannya.

Penggunaan bahasa yang menyalahi skala ini juga terjadi pada kutipan P2.K15 berikut.

bungul nyawa nih. Nyawa tuh pacaran wan tunggul ja. Kada payu ja lagi (Kamu itu bodoh. Kamu itu punya pacar tiang saja. Tidak laku saja lagi). (P2.K15)

Kutipan di atas menunjukkan bahasa yang tidak memiliki kesantunan baik dari segi bahasa secara menyeluruh maupun kata yang ada di dalamnya. Kata bungul (bodoh) merupakan kata yang memiliki makna negatif. Kata ini berupa kata kasar yang ditujukan kepada lawan tutur. Dengan kata ini, orang yang mendengarnya pun kemungkinan akan marah dan membalas apa yang diucapkannya. Kata selanjutnya adalah kata nyawa (kamu). Kata nyawa dalam bahasa Banjar merupakan kata yang kasar, tidak patut diucapkan. Bukan hanya dua kata ini, kata bungul dan nyawa tetapi ketidaksantunan juga tampak pada konteks selanjutnya. Konteks Nyawa tuh pacaran 
wan tunggul ja (Kamu itu punya pacar tiang saja) mengisyaratkan bahwa konteks ini berupa ejekan yang ditujukan kepada lawan tutur. Lawan tuturnya mengejek agar lawan tuturnya punya pasangan tiang saja. Ini juga bertentangan dengan logika yang ada. Manusia hakekatnya memiliki pasangan seorang manusia juga bukan hewan apalagi tiang yang merupakan benda hidup. Konteks ini dianggap tidak memiliki kesantunan. Kemudian, ejekan ini dilanjutkan lagi dengan kata yang mengucapkan bahwa ia tidak laku saja sampai dengan sekarang yang terdapat pada konteks Kada payu ja lagi (Tidak laku saja lagi). Tidak laku disini maksudnya tidak seorang pasangan/ lawan jenis pun yang mau dengannya. Ketidaklakuan seseorang ini menjadi salah satu yang memalukan sehingga ketika diungkapkan konteks ini malah membuat kecanggungan.

\section{SIMPULAN}

Segi skala ketegasan ditemukan ada dua belas konteks yang terjadi pelanggaran, yakni pada (1) percakapan pertama sebanyak dua konteks, yaitu konteks keempat dan kesebelas, (2) percakapan kedua sebanyak tiga konteks, yaitu konteks lima, enam, dan lima belas, (3) percakapan ketiga sebanyak tiga konteks, yaitu konteks kesembilan, kesebelas, keenam belas, dan (4) percakapan keempat sebanyak dua konteks, yaitu konteks kedua, keempat, keenam, kedelapan.

\section{SARAN}

Ada bebarapa hal yang perlu peneliti sarankan, yaitu.

a. Kepada para pengajar agar lebih mengarahkan kepada anak didiknya untuk bertutur kata yang lembut menurut kesantunan yang ada di masyarakat,

b. Para anak didik diharapkan mampu mempraktikkan kesantunan berbahasa, baik dengan sesama teman, tenaga pendidik, maupun yang lainnya, dan

Kesantunan berbahasa sangat perlu dikuasai oleh seorang anak didik yang memiliki pendidikan

dikarenakan salah satu pandangan orang lain kepada seseorang adalah berdasarkan dengan bahasanya

\section{DAFTAR RUJUKAN}

Chaer, Abdul. 2010. Kesantunan Berbahasa. Jakarta: Rineka Cipta.

Eelen, Gino. 2001. Kritik Teori Kesantunan. Diterjemahkan oleh Jumadi dan Slamet Rianto. Surabaya: Erlangga University Press.

Leech, Geoffrey. 1993. Prinsip-Prinsip Pragmatik. Diterjemahkan oleh M.D.D. Oka. Jakarta: Universitas Indonesia Press. 
Moleong, Lexy J. 2005. Metodologi Penelitian Kualitatif. Bandung: Remaja Rosdakarya.

Rahardi, Kunjana. 2005. Pragmatik Kesantunan Imperatif Bahasa Indonesia. Jakarta: Anggota IKAPI Erlangga.

Rahardi, R. Kunjana. 2000. Imperatif dalam Bahasa Indonesia. Yogyakarta: Duta Wacana University Press.

Wijayana, I Dewa Putu dan Muhammad Rohmadi. 2011. Analisis Wacana Pragmatik Kajian Teori dan Analisis. Surakarta: Yuma Pustaka.

Yule, George. 2006. Pragmatik. Diterjemahkan oleh Rombe Mustajab. Yogyakarta: Pustaka Pelajar. 